\section{Temperature Prior to Harvest Influences the Incidence and Severity of Clubroot on Two Asian Brassica Vegetables}

\author{
Mary Ruth McDonald ${ }^{1,3}$ and Sean M. Westerveld ${ }^{2}$ \\ Department of Plant Agriculture, University of Guelph, Crop Science \\ Building, Guelph, Ontario NIG 2W1, Canada
}

Additional index words. Shanghai pak choy, Chinese flowering cabbage, Plasmodiophora brassicae, Brassica rapa subsp. chinensis var. communis, Brassica rapa subsp. chinensis var. utilis

\begin{abstract}
Shanghai pak choy [Brassica rapa L. subsp. chinensis (Rupr.) var. communis Tsen and Lee] and Chinese flowering cabbage [Yow choy; B. rapa L. subsp. chinensis (Rupr.) var. utilis Tsen and Lee] were seeded into organic (muck) soil naturally infested with the clubroot pathogen (Plasmodiophora brassicae Woronin) at the University of Guelph Muck Crops Research Station, Ontario, Canada, in June, July, and Aug. 2001 and May, June, July, and Aug. 2002. At harvest, clubroot incidence and disease severity index (DSI) were assessed. Data from 17 different seedings at the research station over 4 years were used to compare the relationship between disease incidence and DSI and weather conditions during crop development. Clubroot incidence and severity were highest for crops harvested in July and August and lowest for crops harvested in October. Mean air temperatures during crop development ranged from 15 to $22{ }^{\circ} \mathrm{C}$ and were positively correlated with clubroot incidence and severity for both pak choy $(r=0.68)$ and flowering cabbage $(r=0.73)$. The strongest correlations occurred between air temperatures and disease severity over the final $10 \mathrm{~d}$ before harvest $(r=0.82$ for pak choy; $r=0.84$ for flowering cabbage). The research suggests that clubroot damage in Asian Brassica vegetables could be minimized by seeding in early spring and late summer in areas infested with $P$. brassicae.
\end{abstract}

Clubroot, caused by the soilborne protist Plasmodiophora brassicae (Woronin), is a major pest of Brassica crops in Canada and worldwide. Infected roots of Brassica crops swell, blocking the vascular tissues of the roots. As a result, plants can become wilted and stunted. For short-season Asian Brassica crops such as Shanghai pak choy [Brassica rapa $\mathrm{L}$. subsp. chinensis (Rupr.) var. communis Tsen and Lee] and Chinese flowering cabbage [B. rapa L. subsp. chinensis (Rupr.) var. utilis Tsen and Lee], severe symptoms can lead to delayed or variable maturity, rapid wilting during dry periods, and reduced yield. However, not all symptoms of clubroot cause a loss in marketable yield in these crops

\footnotetext{
Received for publication 25 Feb. 2008. Accepted for publication 3 Apr. 2008.

Funding was provided by the Agricultural Adaptation Council through the support of the Ontario Fruit and Vegetable Grower's Association and by the Ontario Ministry of Agriculture, Food and Rural Affairs/University of Guelph Plant Program. We thank Kevin Vander Kooi, Bozena Kornatowska, and the staff of the Muck Crops Research Station for their assistance. We also thank Bruce Gossen and Cathy Bakker for reviewing this manuscript before submission.

${ }^{1}$ Associate Professor.

${ }^{2}$ Postdoctoral Fellow.

${ }^{3}$ To whom reprint requests should be addressed; emailmrmcdona@uoguelph.ca
}

season Brassica crops to reduce damage in the field, including liming, fertilizers, crop rotation, and chemical controls, but these strategies often do not reduce losses in the field to tolerable levels.

Spores of $P$. brassicae germinate readily at soil temperatures at or above $14{ }^{\circ} \mathrm{C}$ and the germination rate increases as temperature increases (Einhorn and Bochow, 1990). It is generally accepted that the optimal soil temperature for disease development is from 18 to $25^{\circ} \mathrm{C}$ (Colhoun, 1952, 1953). However, it is not known how spore germination rate relates to the rate of infection for many crops, including Asian Brassica crops. A daily mean air temperature of $19.5^{\circ} \mathrm{C}$ was required for $100 \%$ infection to occur in a greenhouse study (Buczacki et al., 1978). In addition, clubroot severity on cabbage, Chinese cabbage, mustard, and radish was minimal below $14{ }^{\circ} \mathrm{C}$ and maximized between 20 and $22{ }^{\circ} \mathrm{C}$ (Thuma et al., 1983). The influence of environmental factors on host resistance to $P$. brassicae is poorly understood. Buczacki et al. (1978) suggested that high light during the second and third weeks after seeding increases clubroot severity, probably as a result of an increase in the concentration of glucobrassicin, a precursor to club development.
Niewhof and Wiering (1963) found no effect of temperature on host resistance.

Once the plant is infected by the pathogen, there is a latent period of $\approx 20$ to $25 \mathrm{~d}$ before symptoms develop (ChoongHoe et al., 2000; Grsic-Rausch et al., 2000). The latent period is not well understood, but during this time, the pathogen progresses through the formation of primary plasmodia, release of secondary zoospores, infection of root cortex cells, and formation of secondary plasmodia (Dixon, 2006; Mithen and Magrath, 1992). The length of the latent period is also influenced by air and soil temperatures (Einhorn and Bochow, 1990). The occurrence of secondary plasmodia appears to be associated with elevated auxin and cytokinin concentrations in the roots, which leads to cell division and club formation (Grsic-Rausch et al., 2000). It is not known how air or soil temperature can influence the timing or speed of club formation.

Asian Brassica crops are short-season crops often grown in succession on the same site during the season in Ontario. Given the potential effects of temperature on infection of these crops by the clubroot pathogen, the subsequent latent period, and symptom development, our hypothesis was that clubroot can be managed by growing these crops on infested soil only when soil temperatures are low. The purpose of this study was to determine: 1) the effect of seeding date on the incidence and severity of clubroot; 2) the effect of air temperatures, soil temperatures, and rainfall during the growth period on clubroot incidence and severity; and 3) the critical periods for determining potential incidence and severity of clubroot at harvest.

\section{Materials and Methods}

Seeding date trial. Shanghai pak choy and Chinese flowering cabbage were seeded into organic (muck) soil at the University of Guelph-Muck Crops Research Station, Holland/Bradford Marsh, Ontario, Canada (long. $44^{\circ} 5^{\prime} \mathrm{N}$, lat. $79^{\circ} 35^{\prime} \mathrm{W}$ ) in 2001 and 2002. The site was naturally infested with the clubroot pathogen. Each plot consisted of four rows, $42 \mathrm{~cm}$ apart and $5 \mathrm{~m}$ in length, and was direct-seeded using a StanHay precision seeder (Stan Hay Co., Ashford, UK) with four replications per seeding date. The trials were conducted on separate sites within $50 \mathrm{~m}$ of each other in 2001 and 2002. The seeding date treatments were 25 June, 25 July, and 23 Aug. 2001 and 24 May, 24 June, 24 July, and 23 Aug. 2002. Calcium ammonium nitrate was applied at $200 \mathrm{~kg} \cdot \mathrm{ha}^{-1} \mathrm{~N}$ on all planting dates, and phosphorus and potassium were applied based on soil tests according to Ontario recommendations (Ontario Ministry of Agriculture, Food, and Rural Affairs, 2000).

At harvest on 1 Aug., 12 Sept., and 13 Oct. in 2001 and 4 July, 29 July, 29 Aug., and 11 Oct. in 2002, 30 plants from each plot were collected and assessed. The roots were thoroughly washed and graded for clubroot 
incidence and severity. Disease severity was assessed using a scale from 0 to 3 : $0=$ no clubbing, $1=$ less than $25 \%$ of root system clubbed, $2=25 \%$ to $50 \%$ of root system clubbed and $3=$ greater than $50 \%$ of root system clubbed (Humpherson-Jones et al., 1992). Disease severity index (DSI) was calculated using the following equation (Kobriger and Hagedorn, 1983):

\section{Results}

Seeding date trial. In the seeding date trial conducted in 2001 to 2002, clubroot incidence in 2001 was highest for the July seeding on both pak choy and flowering cabbage and was higher for the June seeding compared with the August seeding on pak choy (Table 2). In 2002, clubroot incidence

$$
\text { DSI }=\frac{\sum(\text { severity class } * \text { number of plants in class }) * 100}{(\text { total number of plants rated }) *(\text { number of classes }-1)}
$$

Multitrial comparison. In addition to the seeding date trials, nine trials containing Shanghai pak choy and Chinese flowering cabbage and one trial of only pak choy were conducted at the Muck Crops Research Station from 1999 to 2002. There were four replications in each trial, and the mean of the four replications was used for comparison with weather conditions. The seeding dates for the additional trials were 1 June and 9 Aug. 1999; 12 June and 24 Aug. 2000; 15 May, 30 May, and 1 June (two trials) 2001; and 21 May, 24 May, and 6 June (only Shanghai pak choy) 2002. The methods of clubroot assessment at harvest were the same for all trials and occurred on 2 July and 21 Sept. 1999; 24 July and 4 Oct. 2000; 11, 16, and 18 July 2001; and 27 June and 2 July 2002. The means of untreated controls along with data from the seven previously described seeding date trials were used in subsequent analysis of the effect of weather conditions during crop development on clubroot incidence and severity.

Weather. Air temperature (Campbell Scientific model HMP35C probe; Campbell Scientific, Edmonton, Alberta, Canada), soil temperatures at 5-, 10-, and 20-cm depth (Campbell Scientific model 107 probe), and rainfall (Campbell Scientific tipping bucket gauge) were collected at an automated weather station located within $75 \mathrm{~m}$ of all research trials. Data were recorded using a CR21X data logger (Campbell Scientific). The air temperatures were recorded on site at a height of $1.2 \mathrm{~m}$, and the weather station was located over a mowed grass surface over organic soil. The weather data for the period between the day after seeding and the day before harvest were compiled for each trial using the weather station data. Data from all trials were pooled for analysis. Temperature and rainfall data for all of the trials are summarized in Table 1.

Analysis of variance was performed on the data from the seeding date trials in 2001 to 2002 combined over years. Means were compared using Fisher's Protected LSD Test. The incidence and severity of clubroot were compared with weather variables using linear correlation analysis. Data were analyzed using Proc Corr and Proc GLM in SAS Version 9.1 (SAS Institute, Cary, NC). A type I error rate of 0.05 was used for all statistical tests. was highest for the May and June seedings and low for the July and August seedings on pak choy, but there were no differences identified for flowering cabbage as a result of variability within the seeding dates. Overall, clubroot incidence was much higher in 2002 than in 2001. Clubroot severity, as determined by DSI at harvest, followed the same pattern as disease incidence in both were higher on pak choy than on flowering cabbage throughout the trial $(P<0.0001)$.

Multitrial comparison. Results from the combined data from 1999 to 2002 showed that clubroot incidence and severity increased with increasing air and soil temperatures for both pak choy and flowering cabbage, especially during the late growth period (Table 3). Air temperatures during the entire period from seeding until harvest were positively correlated with disease incidence and severity for both crops, but soil temperatures at 5-, 10-, and 20-cm depths were not correlated with disease incidence or severity during the same period (Table 3 ). When the season was divided into $10-d$ periods, the highest correlation occurred between air temperatures during the final $10 \mathrm{~d}$ of crop development and disease incidence and severity (Table 3; Fig. 1). There was no correlation between any of the temperature variables and disease incidence or severity during the period between 11 and $20 \mathrm{~d}$ before harvest $(\mathrm{DBH})($ Table 3$)$ or any other $10-\mathrm{d}$ years. Incidence and severity of clubroot

Table 1. Mean air temperature, soil temperatures, and total rainfall between seeding and harvest for trials on Shanghai pak choy and Chinese flowering cabbage conducted at Bradford/Holland Marsh, Ontario, between 1999 and 2002.

\begin{tabular}{|c|c|c|c|c|c|}
\hline \multirow[b]{2}{*}{ Trials/seeding and harvest dates } & \multicolumn{4}{|c|}{ Mean temp during trial $\left({ }^{\circ} \mathrm{C}\right)$} & \multirow{2}{*}{$\begin{array}{l}\text { Total rainfall } \\
\text { during trial } \\
(\mathrm{mm})\end{array}$} \\
\hline & Air & Soil $5 \mathrm{~cm}$ & Soil $10 \mathrm{~cm}$ & Soil $20 \mathrm{~cm}$ & \\
\hline \multicolumn{6}{|l|}{ Seeding date trials } \\
\hline 25 June to 1 Aug. 2001 & 19.5 & 17.0 & 18.0 & 18.6 & 69.8 \\
\hline 25 July to 13 Sept. 2001 & 19.5 & 16.9 & 18.2 & 19.1 & 38.8 \\
\hline 23 Aug. to 12 Oct. 2001 & 14.3 & 13.2 & 14.9 & 16.8 & 105.0 \\
\hline 24 May to 4 July 2002 & 18.4 & 15.2 & 16.0 & 16.4 & 145.5 \\
\hline 24 June to 29 July 2002 & 21.7 & 19.1 & 20.0 & 20.6 & 69.3 \\
\hline 24 July to 29 Aug. 2002 & 20.3 & 18.7 & 19.9 & 21.0 & 58.3 \\
\hline 23 Aug. to 11 Oct. 2002 & 16.6 & 15.2 & 16.8 & 18.8 & 53.3 \\
\hline \multicolumn{6}{|l|}{ Additional trials } \\
\hline 1 June to 2 July 1999 & 19.5 & 16.3 & 17.0 & 16.5 & 49.5 \\
\hline 9 Aug. to 21 Sept. 1999 & 17.9 & 16.7 & 18.6 & 19.9 & 116.0 \\
\hline 12 June to 24 July 2000 & 18.3 & 16.8 & 18.3 & 18.9 & 216.0 \\
\hline 24 Aug. to 4 Oct. 2000 & 15.8 & 14.1 & 16.0 & 17.6 & 114.3 \\
\hline 1 June to 11 July 2001 & 18.4 & 15.5 & 16.2 & 16.7 & 73.0 \\
\hline 30 May to 18 July 2001 & 17.9 & 15.3 & 16.1 & 16.7 & 92.3 \\
\hline 1 June to 16 July 2001 & 18.3 & 15.5 & 16.3 & 16.8 & 73.0 \\
\hline 6 June to 15 July 2002 & 20.1 & 17.4 & 18.3 & 18.8 & 108.0 \\
\hline 24 May to 2 July 2002 & 18.0 & 14.9 & 15.7 & 16.1 & 145.5 \\
\hline 21 May to 27 June 2002 & 16.7 & 13.6 & 14.4 & 15.0 & 145.8 \\
\hline
\end{tabular}

Table 2. Effect of seeding date on the incidence and severity of clubroot caused by Plasmodiophora brassicae on Shanghai pak choy and Chinese flowering cabbage.

\begin{tabular}{|c|c|c|c|c|}
\hline \multirow{2}{*}{$\begin{array}{l}\text { Trial seeding } \\
\text { date/harvest date }\end{array}$} & \multicolumn{2}{|c|}{ Clubroot incidence $(\%)$} & \multicolumn{2}{|c|}{ Clubroot severity $(\mathrm{DSI})^{\mathrm{z}}$} \\
\hline & Pak choy & Flowering cabbage & Pak choy & Flowering cabbage \\
\hline \multicolumn{5}{|l|}{2001} \\
\hline 25 June/1 Aug. & $68.3 \mathrm{~b}^{\mathrm{y}}$ & $31.7 \mathrm{ab}$ & $38.9 \mathrm{~b}$ & $15.6 \mathrm{a}$ \\
\hline 25 July/13 Sept. & $92.5 \mathrm{c}$ & $59.2 \mathrm{~b}$ & $81.4 \mathrm{c}$ & $35.6 \mathrm{~b}$ \\
\hline 23 Aug./12 Oct. & $13.3 \mathrm{a}$ & $1.7 \mathrm{a}$ & $4.4 \mathrm{a}$ & $0.6 \mathrm{a}$ \\
\hline \multicolumn{5}{|l|}{2002} \\
\hline 24 May/4 July & $99.2 \mathrm{~b}$ & $50.0 \mathrm{a}$ & $99.2 \mathrm{~b}$ & $36.9 \mathrm{c}$ \\
\hline 24 June/29 July & $99.2 \mathrm{~b}$ & $50.9 \mathrm{a}$ & $82.8 \mathrm{~b}$ & $33.6 \mathrm{bc}$ \\
\hline 24 July/29 Aug. & $55.9 \mathrm{a}$ & $24.2 \mathrm{a}$ & $40.6 \mathrm{a}$ & $19.2 \mathrm{ab}$ \\
\hline 23 Aug./11 Oct. & $47.5 \mathrm{a}$ & $21.7 \mathrm{a}$ & $35.0 \mathrm{a}$ & $12.0 \mathrm{a}$ \\
\hline
\end{tabular}

${ }^{\mathrm{z}}$ Disease severity index $(\mathrm{DSI})=\left[\sum\right.$ (severity class $*$ number of plants in class $\left.) * 100\right) /(\{$ total number of plants rated $\}) *$ (number of classes-1)]; severity classes: $0=$ no symptoms, $1=1$ ess than $25 \%$ of the root system clubbed, $2=25 \%$ to $50 \%$ of the root system clubbed, $3=$ greater than $50 \%$ of the root system clubbed.

${ }^{y}$ Numbers in a column and a year followed by the same letter are not significantly different at $P=0.05$ based on Fisher's Protected LSD Test. 
Table 3. Linear correlation between clubroot incidence/severity and mean air and soil temperatures during the growth period and during the last 10 and $20 \mathrm{~d}$ before harvest for Shanghai pak choy and Chinese flowering cabbage.

\begin{tabular}{|c|c|c|c|c|c|c|c|c|}
\hline \multirow{3}{*}{$\begin{array}{l}\text { Time interval } \\
\text { and weather variable }\end{array}$} & \multicolumn{4}{|c|}{ Correlation with incidence } & \multicolumn{4}{|c|}{ Correlation with severity } \\
\hline & \multicolumn{2}{|c|}{ Pak choy } & \multicolumn{2}{|c|}{ Flowering cabbage } & \multicolumn{2}{|c|}{ Pak choy } & \multicolumn{2}{|c|}{ Flowering cabbage } \\
\hline & $P$ & $r$ & $P$ & $r$ & $P$ & $r$ & $P$ & $r$ \\
\hline \multicolumn{9}{|l|}{ Season mean } \\
\hline Air & 0.0105 & 0.60 & 0.0078 & 0.64 & 0.0375 & 0.52 & 0.0104 & 0.64 \\
\hline Soil $5 \mathrm{~cm}$ & NS & - & NS & - & NS & - & NS & - \\
\hline Soil $10 \mathrm{~cm}$ & NS & - & NS & - & NS & - & NS & - \\
\hline Soil $20 \mathrm{~cm}$ & NS & - & NS & - & NS & - & NS & - \\
\hline \multicolumn{9}{|c|}{1 to $10 \mathrm{~d}$ before harvest } \\
\hline Air & $<0.0001$ & 0.82 & 0.0006 & 0.76 & $<0.0001$ & 0.82 & $<0.0001$ & 0.84 \\
\hline Soil $5 \mathrm{~cm}$ & 0.0002 & 0.78 & 0.0020 & 0.71 & 0.0010 & 0.74 & 0.0011 & 0.76 \\
\hline Soil $10 \mathrm{~cm}$ & 0.0008 & 0.73 & 0.0038 & 0.68 & 0.0027 & 0.70 & 0.0027 & 0.72 \\
\hline Soil $20 \mathrm{~cm}$ & 0.0052 & 0.65 & 0.0148 & 0.60 & 0.0101 & 0.62 & 0.0119 & 0.63 \\
\hline \multicolumn{9}{|c|}{11 to $20 \mathrm{~d}$ before harvest } \\
\hline Air & NS & - & NS & - & NS & - & NS & - \\
\hline Soil $5 \mathrm{~cm}$ & NS & - & NS & - & NS & - & NS & - \\
\hline Soil $10 \mathrm{~cm}$ & NS & - & NS & - & NS & - & NS & - \\
\hline Soil $20 \mathrm{~cm}$ & NS & - & NS & - & NS & - & NS & - \\
\hline
\end{tabular}

${ }^{\mathrm{N}}$ Nonsignificant.
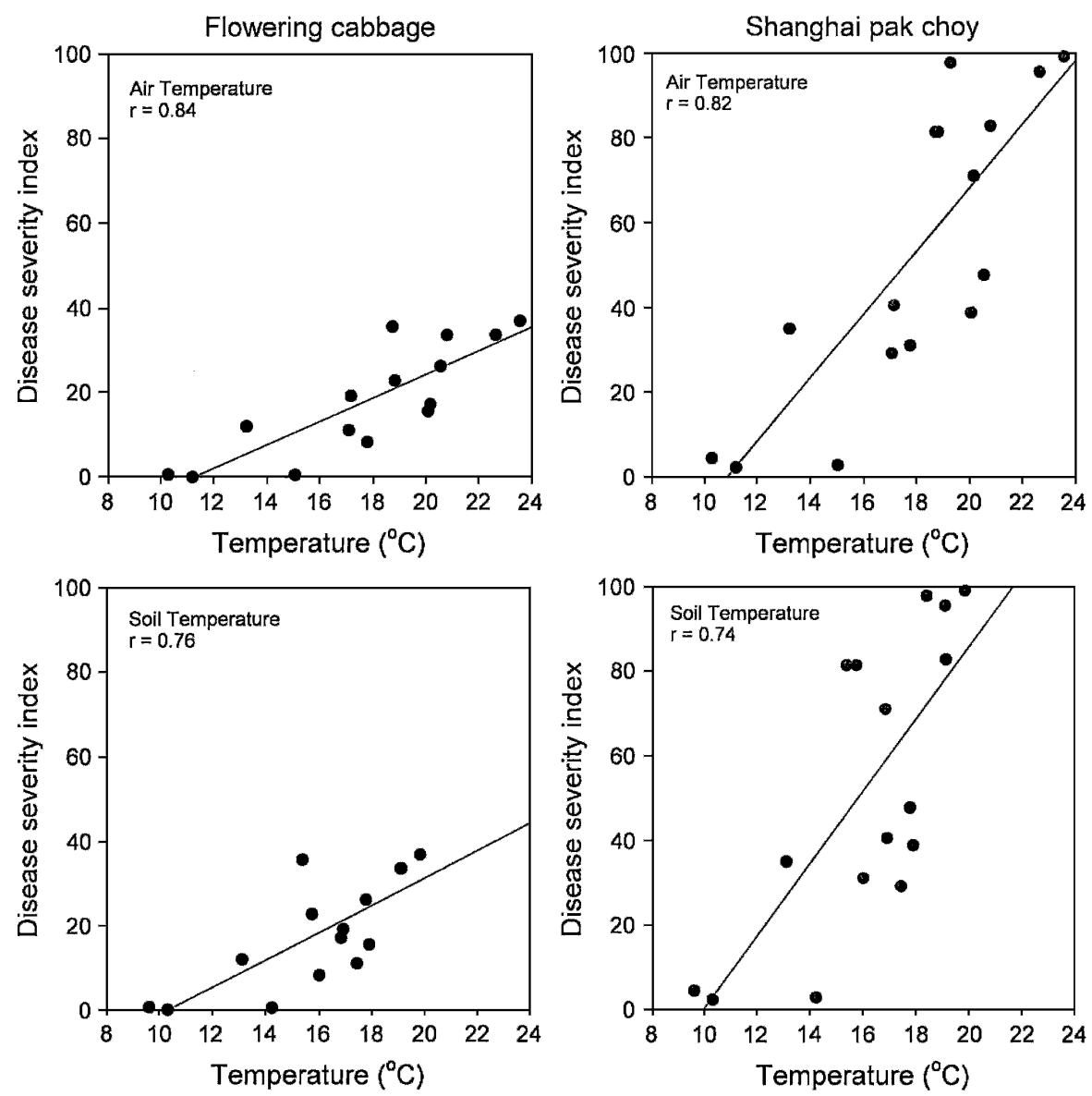

Fig. 1. Effect of mean air temperatures and mean soil temperatures at $5-\mathrm{cm}$ depth during the last $10 \mathrm{~d}$ before harvest on clubroot disease severity index on Chinese flowering cabbage and Shanghai pak choy.

period during the season (data not shown). The correlation coefficients were relatively consistent between incidence and severity and decreased with increasing depth of the temperature measurements in the soil. Minimal symptom development occurred when air temperatures during the final 10 DBH were below $12{ }^{\circ} \mathrm{C}$, and clubroot incidence and severity were highest between 20 and $22^{\circ} \mathrm{C}$ during the same period (Fig. 1).
When the final $15 \mathrm{DBH}$ were divided into 5-d periods, the strongest correlations were between disease incidence and severity and soil temperatures during the final $5 \mathrm{DBH}$ and disease incidence and severity and air temperatures between 6 and 10 DBH (Table 4). There was no correlation between clubroot incidence or severity and air or soil temperatures during the period from 11 to $15 \mathrm{DBH}$. When assessed based on 5-d periods, clubroot development occurred in some trials despite cold temperatures near harvest, and this can be explained by a relatively warmer period between 6 and $10 \mathrm{DBH}$ in most cases (Table 5). Rainfall was not correlated with clubroot incidence or severity during any of the periods examined (data not shown).

\section{Discussion}

Seeding date influences the incidence and severity of clubroot on Shanghai pak choy and Chinese flowering cabbage. Disease incidence and severity were consistently highest for crops harvested during July and August and lowest for crops harvested in October. However, there was a difference between the 2 years in the clubroot incidence and severity in the July seeding date. In 2001, clubroot was severe in the July seeding despite relatively cool conditions during growth. However, in 2002, clubroot was much less severe in the July seeding despite relatively warm conditions during growth. Closer examination of the weather data reveals that, despite a relatively cool end of August and early September for the 2001 July seeding that delayed harvest, there was a warm period that occurred between 3 and 7 DBH. During this period, the mean air temperature was $24.5{ }^{\circ} \mathrm{C}$. By contrast, for the same seeding date in 2002, mean temperatures were warm (mean, $21.6^{\circ} \mathrm{C}$ ) for the first $23 \mathrm{~d}$ after seeding (DAS), resulting in rapid crop development, but in the last $12 \mathrm{DBH}$, the mean air temperature was only $17.3{ }^{\circ} \mathrm{C}$ and $18.5^{\circ} \mathrm{C}$ for the period from 3 to $7 \mathrm{DBH}$.

Based on the results of the correlation analysis, the effect of seeding date on incidence and severity of clubroot can be attributed to differences in air and soil temperatures during the final $10 \mathrm{~d}$ before harvest. Also, we noted that temperature has a similar influence on disease incidence and severity as previously reported (Colhoun, 1953). However, temperature during the 11 to $20 \mathrm{DBH}$ period and earlier was not correlated with incidence or severity. Soil temperatures were slightly less correlated with disease incidence and severity than air temperature, which may be the result of differences between the plots and the weather station where the temperatures were recorded. Because the soil temperature measurements were taken under a mowed grass surface, they would generally be cooler than the soil temperatures in the trial and less responsive to changes in air temperature. Because clubroot develops below the soil surface, soil temperatures at $5-\mathrm{cm}$ depth probably have a significant influence on clubroot development. However, it is possible that the influence of temperature on clubroot development is partly the result of changes in the rate of development of the host, which would be directly affected by air temperature. The research indicates that air temperatures can be an effective indicator of the potential for disease development, which would be useful for instances in which soil temperatures are not available. 
Table 4. Linear correlation between clubroot incidence/severity and mean air and soil temperatures during the interval before harvest for Shanghai pak choy and Chinese flowering cabbage.

\begin{tabular}{|c|c|c|c|c|c|c|c|c|}
\hline \multirow{3}{*}{$\begin{array}{l}\text { Time interval } \\
\text { and weather variable }\end{array}$} & \multicolumn{4}{|c|}{ Correlation with clubroot incidence } & \multicolumn{4}{|c|}{ Correlation with clubroot severity } \\
\hline & \multicolumn{2}{|c|}{$\begin{array}{l}\text { Pak } \\
\text { choy }\end{array}$} & \multicolumn{2}{|c|}{$\begin{array}{l}\text { Flowering } \\
\text { cabbage }\end{array}$} & \multicolumn{2}{|c|}{$\begin{array}{l}\text { Pak } \\
\text { choy }\end{array}$} & \multicolumn{2}{|c|}{$\begin{array}{l}\text { Flowering } \\
\text { cabbage }\end{array}$} \\
\hline & $P$ & $r$ & $P$ & $r$ & $P$ & $r$ & $P$ & $r$ \\
\hline \multicolumn{9}{|l|}{1 to $5 \mathrm{~d}$ before harvest } \\
\hline Air & 0.0009 & 0.73 & 0.0048 & 0.67 & 0.0010 & 0.74 & 0.0012 & 0.75 \\
\hline Soil $5 \mathrm{~cm}$ & 0.0001 & 0.80 & 0.0012 & 0.73 & 0.0004 & 0.78 & 0.0004 & 0.80 \\
\hline \multicolumn{9}{|c|}{6 to $10 \mathrm{~d}$ before harvest } \\
\hline Air & 0.0007 & 0.74 & 0.0025 & 0.70 & 0.0014 & 0.73 & 0.0013 & 0.75 \\
\hline Soil $5 \mathrm{~cm}$ & 0.0028 & 0.68 & 0.0102 & 0.62 & 0.0092 & 0.63 & 0.0098 & 0.64 \\
\hline \multicolumn{9}{|c|}{11 to $15 \mathrm{~d}$ before harvest } \\
\hline Air & NS & - & NS & - & NS & - & NS & - \\
\hline Soil $5 \mathrm{~cm}$ & NS & - & NS & - & NS & - & NS & - \\
\hline \multicolumn{9}{|l|}{${ }^{\mathrm{Ns}}$ Nonsignificant. } \\
\hline \multicolumn{9}{|c|}{$\begin{array}{l}\text { Table } 5 \text {. Mean air temperatures and soil temperatures at } 5-\mathrm{cm} \text { depth during the periods from } 1 \text { to } 5 \text { and } 6 \text { to } \\
10 \mathrm{~d} \text { before harvest (DBH) for clubroot trials on Shanghai pak choy and Chinese flowering cabbage } \\
\text { conducted between } 1999 \text { and } 2002 \text {. }\end{array}$} \\
\hline & & \multicolumn{7}{|c|}{ Mean temp $\left({ }^{\circ} \mathrm{C}\right)$} \\
\hline \multirow{2}{*}{\multicolumn{2}{|c|}{$\begin{array}{l}\text { Trials/seeding and } \\
\text { harvest dates }\end{array}$}} & \multicolumn{3}{|c|}{1 to $5 \mathrm{DBH}$} & & \multicolumn{3}{|c|}{6 to $10 \mathrm{DBH}$} \\
\hline & & $\overline{\text { Air }}$ & & Soil $5 \mathrm{~cm}$ & & $\overline{\text { Air }}$ & & $15 \mathrm{~cm}$ \\
\hline \multicolumn{9}{|l|}{ Seeding date trials } \\
\hline 25 June to 1 Aug. 20 & & 18.3 & & 16.7 & & 21.8 & & 19.1 \\
\hline 25 July to $13 \mathrm{Sept}, 20$ & & 20.7 & & 16.0 & & 16.7 & & 14.7 \\
\hline 23 Aug. to 12 Oct. 20 & & 8.1 & & 8.0 & & 12.5 & & 11.2 \\
\hline 24 May to 4 July 200 & & 25.1 & & 20.7 & & 22.0 & & 18.9 \\
\hline 24 June to 29 July 20 & & 20.2 & & 19.1 & & 21.3 & & 19.1 \\
\hline 24 July to 29 Aug. 20 & & 17.4 & & 16.8 & & 16.9 & & 17.1 \\
\hline 23 Aug. to 11 Oct. 20 & & 9.5 & & 11.1 & & 16.9 & & 15.1 \\
\hline \multicolumn{9}{|c|}{ Additional trials } \\
\hline 1 June to 2 July 1999 & & 19.0 & & 18.2 & & 22.1 & & 17.4 \\
\hline 9 Aug. to 21 Sept. 19 & & 14.1 & & 13.4 & & 16.0 & & 15.1 \\
\hline 12 June to 24 July 20 & & 15.7 & & 16.9 & & 18.5 & & 18.0 \\
\hline 24 Aug. to 4 Oct. 200 & & 14.1 & & 9.9 & & 8.3 & & 10.7 \\
\hline 1 June to 11 July 200 & & 20.2 & & 15.7 & & 15.3 & & 16.3 \\
\hline 30 May to 18 July 20 & & 17.8 & & 15.7 & & 19.9 & & 16.2 \\
\hline 1 June to 16 July 200 & & 17.4 & & 15.7 & & 20.2 & & 15.7 \\
\hline 6 June to 15 July 200 & & 18.1 & & 17.7 & & 20.5 & & 19.1 \\
\hline 24 May to 2 July 200 & & 22.8 & & 19.8 & & 22.4 & & 18.4 \\
\hline 21 May to 27 June 20 & 002 & 22.4 & & 18.4 & & 17.9 & & 15.3 \\
\hline
\end{tabular}

Based on previous research, it is possible to estimate the timing of different stages of the life cycle of $P$. brassicae in our experiments. The period between seeding and harvest for these crops averaged $41 \mathrm{~d}$ and ranged from 31 to $50 \mathrm{~d}$. It is not known how much the timing of optimal temperatures for club development are influenced by host, and consequently, it is difficult to compare the timing of different stages in the life cycle among studies on different crops. However, infection of the roots by zoospores probably occurs $\approx 10$ to 14 DAS (Buczacki et al., 1978; Tommerup and Ingram, 1971). Under optimal conditions, the latent period would last $\approx 14 \mathrm{~d}$ (Tommerup and Ingram, 1971) and under field conditions, this period has been suggested to last 20 to $25 \mathrm{~d}$ (ChoongHoe et al., 2000; Grsic-Rausch et al., 2000). Thus, symptom development would likely begin 24 to 39 DAS. Einhorn and Bochow (1990) defined the incubation period as the period between seedling emergence and symptom development. In that study, there was a negative linear relationship between temperature and the length of the incubation period. The length of the incubation period could be described using the following equation (Einhorn and Bochow, 1990):

Incubation period $=73.74-2.55 \times$

(soil temperature)

Using this equation and assuming seedling emergence occurs 4 DAS, symptoms would develop in the range of 27 to 42 DAS in our studies. Using either of these estimates, club development would begin within the last $10 \mathrm{DBH}$ for all crops in our study, so the effect of temperature during the final $10 \mathrm{DBH}$ is primarily on club development. Because air or soil temperatures in earlier periods of crop development did not have much influence on clubroot incidence or severity, it is possible that infection by $P$. brassicae and subsequent development in the roots has a similar optimal temperature as the host plant. If this is the case, then conditions that favor rapid crop development also favor rapid progression of $P$. brassicae through different stages in the roots. Our research indicates that the optimal temperature for club development may differ from that of the host.

Rainfall was not correlated with disease incidence or severity. Because plots were irrigated before seeding if necessary, and the crops were only in the field for 31 to $50 \mathrm{~d}$, soil moisture would have been adequate throughout the season, regardless of rainfall, as a result of the high waterholding capacity of the organic soil.

Overall, the research indicates that several strategies can be used to reduce clubroot severity in Asian Brassica vegetables in Ontario. Seeding susceptible crops in early spring, earlier than the late May planting in this study, or in August or September could effectively minimize disease severity in most cases. This strategy was also suggested for cauliflower in Germany (Einhorn and Bochow, 1990). Over the summer months, nonsusceptible crops can be grown. If this is not possible, it is likely that any strategy that will keep soil temperatures cool during the final $10 \mathrm{DBH}$ will also reduce the severity of the disease. The use of organic or reflective mulches has been effective in reducing soil temperatures for other crops (Davis et al., 1970) and may minimize clubroot if mulches can be incorporated into the production system. Other strategies could include timely irrigation or living mulches. It is also possible that season-extending strategies such as row covers could potentially increase clubroot severity if soil temperatures are increased.

In summary, clubroot on Asian Brassica crops was influenced by air and soil temperatures during the late growth period. This effect was consistent among crops and years. Thus, methods to reduce temperatures during this period could reduce the severity of clubroot. Combining these methods with existing control strategies could prevent major losses resulting from clubroot in the field.

\section{Literature Cited}

Buczacki, S.T., J.G. Ockendon, and G.H. Freeman. 1978. An analysis of some effects of light and soil temperature on clubroot disease. Ann. Appl. Biol. 88:229-238.

ChoongHoe, K., C. WonDae, and K. HongMo. 2000. Yield loss of spring Chinese cabbage as affected by infection time of clubroot disease in fields. Plant Dis. Res. 6:23-26.

Colhoun, J. 1952. Factors affecting the incidence of club root disease of Brassicae. Nature 169: 21-22.

Colhoun, J. 1953. A study of the epidemiology of club-root disease of Brassicae. Ann. Appl. Biol. 40:262-283.

Davis, D.R., R.R. Kincaid, and F.M. Rhodes. 1970. Mulches reduce soil temperatures under tomato and tobacco plants in Florida. Proc. 83rd Annual Meeting Fla. State Hort. Soc. 83:117119.

Dixon, G.R. 2006. The biology of Plasmodiophora brassicae Wor.-A review of recent advances. Acta Hort. 706:271-282.

Einhorn, G. and H. Bochow. 1990. The effects of temperature and $\mathrm{pH}$ value on the pathogenesis of Plasmodiophora brassicae Wor., the causal agent of clubroot. Arch. Phytopathol. Pflanzenschutz 26:131-138.

Grsic-Rausch, S., P. Kobelt, J.M. Siemens, M. Bischoff, and J. Ludwig-Müller. 2000. 
Expression and localization of nitrilase during symptom development of the clubroot disease in Arabidopsis. Plant Phys. 122:369-378.

Humpherson-Jones, F.M., G.R. Dixon, M.A. Craig, and D.M. Ann. 1992. Control of clubroot using calcium cyanamide-A review. Brit. Crop Protection Conf.-Pests and Diseases 3:1147-1154.

Kobriger, K.M. and D.J. Hagedorn. 1983. Determination of bean root rot potential in vegetable production fields of Wisconsin's Central Sands. Plant Dis. 67:177-178.
Mithen, R.F. and R. Magrath. 1992. A contribution to the life history of Plasmodiophora brassicae: Secondary plasmodia development in roo galls of Arabidopsis thaliana. Mycol. Res. 96:877-885.

Niewhof, M. and D. Wiering. 1963. Factors influencing the occurrence of clubroot in semiresistant populations of Brassica oleracea L. Euphytica 12:270-276.

Ontario Ministry of Agriculture Food and Rural Affairs. 2000. Vegetable production recom- mendations. Publ. 363, Queen's Printer for Ontario, Toronto, Canada.

Thuma, B.A., R.C. Rowe, and L.V. Madden. 1983. Relationships of soil temperature and moisture to clubroot (Plasmodiophora brassicae) severity on radish in organic soil. Plant Dis. 67:758762 .

Tommerup, I.C. and D.S. Ingram. 1971. The lifecycle of Plasmodiophora brassicae Woron. in brassica tissue cultures and intact roots. New Phytol. 70:327-332. 